\title{
LA VOLUNTAD TOTALITARIA DEL FRANQUISMO
}

THE TOTALITARIAN WILL OF FRANCHISM

Luis aurelio GonzÁlez Prieto'

Resumen: A mediados de los años sesenta del siglo pasado surge con fuerza y apoyado por el propio régimen franquista la caracterización de que el sistema político instaurado por el general Franco había sido solamente autoritario y no totalitario. Pese a los intentos de la doctrina política alineada con su defensa de eximirlo de toda veleidad totalitaria, las circunstancias políticas en las que se inscribe a finales de los años treinta y comienzos de los cuarenta son de una clara e inequívoca voluntad totalitaria. La pretensión de constituir un Estado que se debía totalizar al servicio del catolicismo era defendida por el propio general Franco y la práctica totalidad de la doctrina política que lo apoyaba. Para inscribir el Estado español de aquella época entre las realidades estatales totalitarias se desarrollaron varías teorías como: el Totalitarismo Humanista, el Totalitarismo Subjetivo, el Totalitarismo Solidarista o la de España como una Gran Potencia Espiritual Totalitaria.

Palabras Glave: Totalitarismo, Autoritarismo, Catolicismo, Imperio, Gran Potencia Espiritual.

Abstract: In the 1960s there was a forceful attempt, supported by Franco's own regime to characterise the political system established by General Franco as simply authoritarian rather than totalitarian. Despite efforts by defenders of the regime to

${ }^{1}$ Licenciado y Doctor en Derecho por la Universidad de Oviedo; profesor del Instituto "Rey Pelayo" en Cangas de Onís, Asturias; profesor invitado de la Universidad Nacional de Educación a Distancia y Miembro del Real Instituto de Estudios Asturianos. Contacto: <laureligp@gmail.com>. ORCID: < https://orcid. org/0000-0002-2408-2739>.

Fecha de recepción: 21 de mayo de 2020; fecha de aprobación: 6 de agosto de 2020. 
construct a doctrine that would exempt it from any totalitarian leaning, the political circumstances in which it came to existence in the 30 s and the early 40 s indicate a clear and unmistakable totalitarian will. The purpose of constructing a State entirely dedicated to the service of catholicism was proclaimed by General Franco himself and virtually all the political doctrine that supported him. In order to inscribe the Spanish state among the actual totalitarian regimes of the time, various theories were developed, such as those of a "Humanist Totalitarianism," "Subjective Totalitarianism," "Mutual Help Totalitarianism," or the notion that Spain was a Totalitarian Spiritual Superpower.

Keywords: Totalitarianism, Authoritarianism, Catholicism, Empire, Spiritual Superpower

Sumario: I. Introducción; II. La inicial inclinación totalitaria del régimen franquista; III. Un Estado totalitario al servicio del catolicismo; IV. España una gran potencia católica totalitaria; V. El nacional-sindicalismo como totalitarismo humanista; VI. El totalitarismo subjetivo de los católicos; VII. El Estado hispánico totalitario solidarista: VIII. A modo de conclusión; IX. Fuentes.

\section{I.INTRODUCCIÓN}

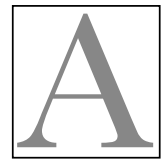

mediados de los años sesenta del siglo pasado, surge con fuerza en el contexto de caracterización la tesis expuesta por el sociólogo Juan J. Linz Storch de Gracia en el que calificaba el régimen franquista como simplemente autoritario y no totalitario. La tesis expuesta por Linz seguía las diferencias previamente expuestas por Carl J. Friedrich y Z. K. Brzezinski, en su obra Totalitarian Dictatorship and Autocracy², Harper, New Cork,

${ }^{2}$ Carl J. Friedrich y Z. K. Brzezinski, en su obra: Totalitarian Dictatorship and Autocracy, Harper, New York, 1956. 
1956, donde se esgrimía que el "cristianismo auténtico, protestante o católico, no puede aceptar lo totalitario, porque el cristianismo reclama su derecho al hombre total, y a pronunciar la última palabra en relación con sus valores y destinos. Esto no pueden aceptarlo los totalitarismos". De parecida manera se manifestaba J. J. Linz cuando decía: "Dada la distinción entre Iglesia y Estado y el internacionalismo de la Iglesia, así como la autoridad del Papa, el empleo de una ideología conservadora católica limita por sí solo toda tendencia monolítica hacia el totalitarismo"s. Tesis que había sido ampliamente difundida por el propio régimen en sus postrimerías.

En el año 2011, los medios de comunicación vuelven a hacerse eco de la caracterización del régimen franquista como un simple régimen autoritario. La causa fue la publicación en el volumen n $^{\circ} 20$ del Diccionario Biográfico Español de la biografía del general Francisco Franco, escrita por el historiador Luis Suárez Fernández, igualmente muy comprometido con el régimen ${ }^{4}$, en la que se afirmaba que el General Franco "Montó un régimen autoritario, pero no totalitario".

Pese a los constantes intentos por desprender al franquismo de todas sus connotaciones totalitarias por parte de algunos miembros de la historiografía política afines o con cierta sintonía con el régimen, la realidad se vuelve muy terca, pues los discursos y declaraciones del propio Franco, así como de los principales jerarcas del régimen, los principios programáticos de la Falange investidos de rango constitucional, la propia legislación y, sobre todo, la doctrina política que apoyaba al régimen se hacen eco, en los primeros tiempos, de la

3 Juan J. Linz, "An Authoritarian Regimen: The Case of Spain", en Eric Allard e Yrjo Littunen (comps), Clevages, Ideologies, and Party Systems, Westermarck Society, 1964. Dicho trabajo fue publicado en castellano en "Una teoría del régimen autoritario. El caso de España", en Manuel Fraga y otros, La España de los años setenta III: El Estado y la política, Madrid, Moneda y Crédito, 1974.

4 Ángel Viñas, La otra cara del Cuadillo. Mitos y realidades en la biografia de Franco, Barcelona, Crítica, 2019, pág. 52. 
imperiosa necesidad de la implantación de un estado totalitario en España. En este sentido, la doctrina política elabora toda una serie de teorías que justifican la inclusión del Estado español franquista dentro de la órbita de los que se consideraban modernos estados totalitario. Un Estado que se totalizaba al servicio del catolicismo y pretendía reconstituir un imperio espiritual católico.

II. LA INICIAL INCLINACIÓN TOTALITARIA DEL RÉGIMEN FRANQUISTA

La noche del 1 de octubre de 1936, el General Franco, tras ser proclamado Jefe del Estado Español, establecía como directriz a seguir por su nuevo Estado la construcción de un sistema totalitario. En febrero de 1937, el propio Franco volvía a manifestar al corresponsal del New York World Telegram: "Cuando la victoria corone nuestro esfuerzo, la nueva España regresará bajo los principios del Estado totalitario". Daba a entender que en España la organización totalitaria del Estado no era algo novedoso, como en el resto de los países europeos, ya que en su configuración histórica España ya había adoptado la forma totalitaria en la época imperial.

El 19 de abril de 1937 con la promulgación del Decreto de Unificación de todas las fuerzas políticas ${ }^{6}$ se asumen con rango programático-constitucional los veintiséis puntos de la Falange ${ }^{7}$, en uno de los cuales se enunciaba que "el Estado es un instrumento totalitario al servicio de la integridad de la Patria". En el mismo preámbulo se comparaba a España con los demás países de régimen totalitario y se manifestaba, en el artículo $2^{\circ}$, que se estaban realizando "los trabajos necesarios encaminados a la organización

${ }^{5}$ D. Sueiro y B. Díaz Nosty, Historia del franquismo, Madrid, Sarpe, 1986, pág. 133.

${ }^{6}$ Vid. Luis Aurelio González Prieto, "La concreción teórica del Partido Único franquista" en la Revista de Estudios Políticos, No 141, 2008.

${ }^{7}$ Luis Aurelio González Prieto, "El debate sobre la Constitución en el primer franquismo", Revista de Estudios Políticos, n 155, pág. 228 y 229. 
definitiva del Nuevo Estado Totalitario". Ese mismo año, en unas declaraciones al enviado de United Press, en julio de 1937, Franco asegura que España "seguirá la estructura de los regímenes totalitarios como Italia y Alemania”. También en las declaraciones realizadas por Franco a William P. Carney, publicadas en The New York Magazine, el 26 de diciembre de 1937, explicaba que "España tiene su propia tradición y la mayoría de las fórmulas modernas que han de ser descubiertas en los países totalitarios pueden ser encontradas ya incorporadas a nuestro pasado nacional". Volverá el General a hacer referencia a la organización del Estado totalitario en la entrevista con el enviado especial del periódico brasileño fornal do Brasil, en enero de 1938, donde dirá: "España se organizará en un amplio concepto totalitario, por medio de instituciones nacionales que aseguren su totalidad, su unidad y continuidad". En 1939, en el preámbulo de la Ley de Constitución del Instituto Nacional del Libro, se declaraba al régimen como abiertamente totalitario. La doctrina política oficial, de acuerdo con las consignas del propio régimen, lo calificaba como un Estado que estaba inmerso en la "constelación totalitaria".

${ }^{8}$ Palabras del Caudillo, Madrid, ed. F.E., 1939, pág. 148 y 226.

${ }^{9}$ Joaquín Garrigues, "Il nuovo ordine in Spagna, sindicati verticali e corporazioni", en Archivio di Studi Corporativi, Roma, 1939, pág. 165: "<<La Spagna si organizza secondo un'ampia concezione totalitaria >> ha detto Franco già nel gennaio del 1938, e infatti già durante la guerra la Spagna si stava organizzando secondo il grande stile degli Stati totalitari”. César Silió, Trayectoria y significación de España: Del tiempo viejo al tiempo nuevo, Madrid, Espasa-Calpe, 1939, pág. 184. En esta misma línea Pedro Laín Entralgo, en Los valores morales del Nacionalsindicalismo, Madrid, 1941, pág. 34, se refiere al "Nacionalsindicalismo como todos los movimientos llamados totalitarios o fascistas". Existe una publicación anterior de esta ponencia de Laín en el I Congreso Sindical de la Falange, Madrid, 1940. Antonio Tovar, en "Valor histórico y filosófico del sindicalismo", en el I Congreso Sindical de la Falange, Madrid, 1940, pág. 170, dice también "como nuestros mismos movimientos totalitarios". Miguel Fenech, La posición del juez en el Nuevo Estado, Madrid, Espasa-Calpe, 1941, pág. 86, dirá expresamente: "España aparece como otro Estado totalitario". 
III. Un Estado TOTALITARIO AL SERVICIO DEL CATOLICISMO

El totalitarismo español, como todos los totalitarismos, necesitaba de una ideología palingenética que aportase una idea-límite finalista absorbente capaz de estructurar un Estado que modelase totalmente al hombre para conseguir la absoluta perfección humana ${ }^{10}$. El totalitarismo español asumirá como idea límite-finalista la defensa y expansión de la religión católica en el mundo, porque es algo que considera consustancial a la propia esencia nacional española. Como expone Jiménez Campo, la unidad, la fraternidad, así como la concepción del mundo y de la vida, las halla el franquismo en el catolicismo ${ }^{11}$, porque entre otras cosas era el principal elemento ideológico que unía a todos los grupos políticos que apoyaron el levantamiento militar ${ }^{12}$. El propio Franco lo dejaba claro en el discurso pronunciado con motivo del Decreto de Unificación, en el que explicaba cuál era el perfil del nuevo Estado: “el que se señaló en octubre del pasado año y que vamos cumpliendo con paso firme y sin vacilaciones. El que es común a la mayoría de los españoles no envenenados por el materialismo o el marxismo. El que figura en el credo de Falange Española. El que encierra el espíritu de nuestros

${ }^{10}$ Vid. Francisco Sevillano Calero, "Totalitarismo, fascismo y franquismo: el pasado y el fin de las certidumbres después del comunismo", en Roque Moreno Fonseret y Francisco Sevillano Calero (eds.), El franquismo. Visiones y balances, Universidad de Alicante, 1999, pag. 24. También en Emilio Gentile, "El fascismo y la vía italiana al totalitarismo", en Manuel Pérez Ledesma (comp.), Los riesgos para la democracia. Fascismo y neofascismo, Madrid, Pablo Iglesias, 1997, págs. 19 a 24.

${ }^{11}$ Javier Jiménez Campo, "Rasgos básicos de la ideología dominante 1939 - 1945”, en la Revista de Estudios Políticos, nº 15, nueva época, 1980, pág. 92.

${ }^{12}$ Manuel Ramírez, "La ideología en el régimen totalitario. El caso de España", en Manuel Ramírez y otros, Las fuentes ideológicas de un régimen (España 1939-1945), Zaragoza, Pórtico, 1978, pág. 17, donde recalcará que "el discurso ideológico que se elabora viene a ser un discurso de circunstancias con apelaciones a lo que une a dichos grupos, con silencio sobre lo que separa". Así como Ricardo Chueca y José Ramón Montero, "Fascista y católico: el pastiche ideológico del primer franquismo", Revista de Occidente, n 223, diciembre de 1999, pág. 14 y 15. 
tradicionalistas [...]. El que atesora la doctrina católica que la totalidad de la nación profesa" ${ }^{13}$. Así pues, el paradigma totalitario misional-cristiano se convierte en el estandarte ideológico del régimen ${ }^{14}$, en boca del propio Franco: "El Estado español tomará muy a pecho nuestra expansión misionera en el mundo, como parte importantísima de la obra civilizadora" ${ }^{15}$. En este sentido, Inkeles reconoce que la ideología-mística-finalista, que utiliza el Estado totalitario como mero instrumento, se encontraba en las leyes dialécticas de la historia y su desarrollo social para los marxistas, en el destino de la nación y de la raza para los hitlerianos o en el ideal de una verdadera sociedad cristiana para Franco ${ }^{16}$.

Este elemento católico es la nota de identidad más importante con la que cuenta el fascismo español; por eso Giménez Caballero sostendrá que la tarea de interpretar el "genio de Roma, la nueva catolicidad", sólo podía estar reservada al "Fascismo", y esa nueva catolicidad -que representa el fascismo- se "apresta a cumplir la eterna misión católica de Roma" ${ }^{17}$. La misión crucial del fascismo español debía tener necesariamente una modalidad católica ${ }^{18}$. Asímismo, el Marqués de Eliseda mantenía que el fascismo era católico en el fondo y, debido a la consustancialidad de la historia de España con el catolicismo, "un nacionalismo que merezca el

${ }^{13}$ Palabras del Caudillo, ob. cit., pág. 15.

${ }^{14}$ Vid. Javier Jiménez Campo, "Crisis política y transición al pluralismo en España (1975-1978)", en Alberto Predieri y Enrique García de Enterría, La Constitución española de 1978, Madrid, Civitas, 1980, pág. 52.

${ }^{15}$ Palabras del Caudillo, ob. cit, pág. 196.

${ }^{16}$ Alex Inkeles, "Totalitarism and Ideologie", en la obra de Carl J. Friedrich (ed.), Totalitarism, Cambridge, Harvard University Press, 1954, pág. 91.

${ }^{17}$ Ernesto Giménez Caballero, La nueva catolicidad. Teoría general sobre el Fascismo en Europa: en España, Madrid, La Gaceta Literaria, 1933, págs. 117 y 120.

${ }^{18}$ Ernesto Giménez Caballero, "Ripercussioni del fascismo in Ispagna”, Gerarchia, Roma, 1932, pág. 812. 
nombre de español tiene que ser eminentemente católico"19. El mismo autor expondrá, en plena guerra civil, que el movimiento nacional es propiamente fascista, pero su fascismo es más positivo e integral porque tiene como misión implantar el Estado nacional católico, que no es ni más ni menos que la actualización del viejo Estado español de la época imperial, ya que para él la monarquía española de la época imperial había sido la organización política menos imperfecta que había existido en el devenir histórico ${ }^{20}$. En consecuencia, los mismos valedores del régimen califican el fascismo español como un fascismo católico ${ }^{21}$. El sentido católico del fascismo español fue asumido por la casi totalidad del movimiento falangista en el proceso de ósmosis ideológica que supuso la guerra civil. Esta ósmosis ideológica configurará un régimen de marcado carácter reaccionario, integrista y contrarrevolucionario ${ }^{22}$.

${ }^{19}$ Moreno Herrero (Marqués de la Eliseda), Fascismo, Catolicismo, Monarquía, Madrid, Fax, 1935, pág. 171.

${ }^{20}$ Marqués de la Eliseda, El sentido fascista del Movimiento Nacional, Santander, Aldus, 1939, pág. 30-31.

${ }^{21}$ José Pemartín, Qué es $<<$ lo nuevo >>, Madrid, Espasa-Calpe, 1940, pág. 36. Los estudiosos del régimen también utilizarán estas calificaciones, en el mismo sentido lo denomina Elías Díaz, Notas para una historia del pensamiento español actual, Madrid, Edicusa, 1974, pág. 33; y en El pensamiento español en la era de Franco, Tecnos, Madrid, 1983, pág. 30. Benjamín Oltra y Amando de Miguel lo calificarán como fascismo frailuno, en Amando de Miguel "La <<Sociología del Franquismo>> revisada", Papers, n 6, 1976, pág. 179; también en Benjamín Oltra y Amando de Miguel, "Bonapartismo y catolicismo: una hipótesis sobre los orígenes ideológicos del Franquismo", revista Papers, $\mathrm{n}^{\circ}$ 8, Barcelona, 1978, pág. 82. Carlos M. Rama La crisis española del siglo XX, Madrid, F. C. E., 1976, pág. 349, "el totalitarismo (español) es el de la fe". Como "dictadura clerical fascista" lo designó George Hills, Monarquía, República y Franquismo, 1868-1974, Madrid, San Martín, 1975, pág. 30. De parecida manera lo conceptuó Enrique Gomáriz, "La reproducción del pasado", en Manuel Tuñón y otros, Ideologíay sociedad en la España contemporánea. Por un análisis del franquismo, Madrid, Cuadernos para el Dialogo, 1977, pág. 306, al referirse al franquismo como una "dictadura militar con rasgos clerical fascistas". También en Manuel Pérez Ledesma, en "Una Dictadura <<Por la Gracia de Dios>>”, Historia Social, n 20, 1994, pág. 182.

${ }^{22}$ Vid. Alfonso Botti, "El franquismo en la historiografía italiana y la mirada del 
Por lo tanto, el régimen franquista consigue el consenso absoluto y la movilización permanente, propias de las tendencias totalitarias, convirtiéndose en un Estado pretendidamente misional, que actúa como "brazo de la catolicidad en la Historia del Mundo" ${ }_{23}$. Como afirma Pedro Cantero, es "un Estado que quiere convertirse en campeón del catolicismo", debido a que "realiza el propio apostolado de Cristo dentro de las instituciones del nuevo Estado Español" ${ }^{24}$. La apostasía de las masas y las nuevas circunstancias históricas de los Estados llamados totalitarios ${ }^{25}$ son las que llevan al nuevo apostolado católico a tener que "atemperarse al ambiente general de los tiempos en los métodos tácticos de su realización” ${ }^{26}$. Según Menéndez Reigada, son esos nuevos tiempos y circunstancias políticas los que impondrán en España un "Estado totalitario cristiano" ${ }_{27}$, que reconozca únicamente a Dios como fuente de derechos y deberes de la persona y que intervenga más o menos en todas las actividades de la vida aceptando a Dios como el único vértice de todo y desde su cúspide infinita bajar "al llano de las cosas para saturarlas de su divina esencia y envolverlas en un totalitarismo

otro sobre los relatos de otras miradas", Ayer; n 31, 1998; y Glicerio Sánchez Recio, "La coalición reaccionaria y la confrontación política dentro del régimen franquista", en Javier Tusell, Julio Pecharroman y Feliciano Montero, Estudios sobre la derecha española contemporánea, Madrid, U.N.E.D., 1993. La contrarrevolución solo podía ser entendida a la manera maeztuiana, como contrarreforma, vid. Ramiro de Maeztu, La Nación, 4 de abril de 1927. También en Alfonso Botti, Cielo y dinero. El Nacionalcatolicismo en España (1881-1975), Madrid, Alianza, 1992, pág. 69.

${ }^{23}$ Federico de Urrutia, Por qué la Falange es Católica, Madrid, 1942. pág. 38.

${ }^{24}$ Pedro Cantero, La hora Católica en España, Madrid, Ruta, 1942, pág. 81.

${ }^{25}$ Vid. Salvador de Lissarrague, "Estado y partido en la coyuntura española", Arriba, 15 de septiembre de 1940 y José Antonio Maravall, "El totalitarismo, régimen europeo", Arriba, 26 de septiembre de 1940, en el que defendían el totalitarismo como régimen europeo fuera del cual era perfectamente imposible vivir políticamente en ella.

${ }^{26}$ Pedro Cantero, ob. cit., pág. 84.

${ }^{27}$ Ignacio G. Menéndez Reigada, Catecismo patriótico español, Salamanca, 1937, pág. 46. 
divino" ${ }^{28}$. El filofascita rumano Mihail Manoilesco llegó a denominar el Estado español como el "Estado cristiano en toda su pureza y con toda su fe". En su opinión, el Estado ético español en su concepción más intransigente busca la garantía suprema del Todopoderoso en todas las instituciones humanas ${ }^{29}$. Como reconocía el propio Papa: "Dios quiere hacer de España un pueblo católico desde las alturas del poder" ${ }^{30}$.

En consecuencia, el Estado totalitario español se convirtió en un verdadero instrumento de apostolado católico ${ }^{31}$ que impregnó con su realidad vital todos los aspectos de la sociedad intentando convertirla en unidimensionalmente católica ${ }^{32}$. Esta sociedad unidimensional católica consideró como elementos más perjudiciales los movimientos que propugnan las ideas materialistas-ateizantes ${ }^{33}$,

${ }^{28}$ Isidro Gomá, "Lecciones de la guerra y deberes de la paz", citado por Alfonso Álvarez Bolado, El experimento del Nacionalcatolicismo (1939-1975), Madrid, Cuadernos para el Dialogo, 1976, pág. 199.

${ }^{29}$ Cfr. Mihail Manoilesco, El Partido Único, Zaragoza, 1938, pág. 199.

${ }^{30}$ Alfonso Álvarez Bolado, ob. cit., pág. 198.

${ }^{31}$ Luis Legaz Lacambra, Panorama Político Español Contemporáneo, Madrid, Colegio Mayor Universitario "Marqués de la Ensenada", 1968, pág. 2 y 8, interpretaba "que no debe sentirse demasiado complejo en llamar totalitario al tipo de Estado que se forjó en aquella época. Pues un Estado no es totalitario sólo porque su ideología sea totalitaria, en el sentido de ser la ideología fascista o nacionalsocialista, sino en primer término, por imponer como prevaleciendo (totalitariamente, pues, podríamos decir) una idea, cualquiera que sea su signo y contenido; y en segundo, porque con independencia de lo anterior - pero tanto si está en conexión con lo anterior - interviene en todos los ámbitos de la vida, o en un gran sector de ella, con las consiguientes limitaciones de la libertad individual", y llegaría a decir que la idea del Estado que ha querido realizarse en España y ha sido la dominante es la de que "El totalitarismo existente se hallaba al servicio de una ideología no totalitaria", como para él era el catolicismo.

${ }^{32}$ Manuel Abellán y Jeroen Oskam, "Función social de la censura eclesiástica. La crítica de libros en la revista Ecclesia", fournal of Interdisciplinary Literary Studies, $\mathrm{N}^{\mathrm{o}} 1$, 1989, pág. 118, señala que las ideas políticas del sector católico estaban encaminadas "hacia la catolización totalitarizante de la sociedad y del régimen".

33 Ignacio Menéndez Reigada, en Catecismo patriótico español, ob. cit., pág. 26, enumera las fuerzas antipatria: "los elementos o partidos separatistas, los partidos de 
que, curiosamente, coincidían con los enemigos de las clases oligárquicas españolas ${ }^{34}$. El catolicismo totalitario españo ${ }^{35}$ no dudará en lo más mínimo en imponer una verdadera propedeútica del terror llegando a la eliminación física de gran número de disidentes.

El nuevo hombre que quiere crear la España franquista está empapado en su esencia nacional por lo religioso, porque quiere conseguir ganar la salvación eterna como destino último de todos los españoles ${ }^{36}$. Julián Pemartín sostenía que la verdad suprema a la que sirve el Estado totalitario español falangista es la unidad de destino. Y el destino de la nueva España no es otro que el defender la unidad católica, el mismo que tenía en su plenitud imperial.

En la España de la posguerra el Estado conseguirá establecer un importante grado de unanimidad en la propia vida de los españoles, la cual quedará modelada y condicionada por lo católico ${ }^{37}$ : los usos del

izquierda, con sus respectivas internacionales marxista y masónica-judaica, sus logias y demás sociedades secretas, sus Ligas de derechos del hombre, Sociedad de amigos de Rusia, Socorro Rojo Internacional, etc.”. Junto con los liberales compartirán el título de antiespañoles "los masones y los comunistas, los republicanos y los separatistas" en José Antonio Portero, "La Revista de Estudios Políticos (1941-1945), en Manuel Ramírez y otros, Las fuentes ideológicas de un régimen (España 1939-1945), Barcelona, Labor, 1978, pág. 40. Cfr. M. Richards, "Constructing the Nationalist State. Self Sufficiency and Regeneration in the Early Franco Years", en Claire Mar-Molinero y Angel Smith (edts.), Nationalism and the Nation in the Iberian Peninsula, Washington/ Oxford, Berg, 1996, peg. 153.

${ }^{34}$ Cfr. A. Sáez Alba, La otra $<<\cos a$ nostra $>>$, la Asociación Católica Nacional de Propagandistas, París, Ruedo Ibérico, 1974. pág. XXIII.

${ }^{35}$ Élène de la Souchère, «Un Catolicisme Totalitaire», Les Temps Moderns, $\mathrm{n}^{\circ}$ 100, París, 1954, pag. 1690. Así mismo Jacques Maritain, Les droits de l'homme et la loi naturelle, New York, La Maison française, 1942, pag. 43 y 44, insertaba al régimen franquista como dictadura de tipo totalitario clerical.

${ }^{36}$ Pedro Laín Entralgo, "Idea falangista del hombre", en la Revista del Colegio Mayor "Fiménez Cisneros, Universidad de Madrid, n 2, 1943, pág. 15.

37 Vid. Rafael Gómez Pérez, Política y religión en el régimen de Franco, Barcelona, Dopesa, 1976, pág. 156: "La religión era un elemento natural de la vida social: las navidades, con los belenes y cabalgatas de los reyes magos; las conferencias cuaresmales y ejercicios espirituales abiertos o cerrados; novenas; las procesiones de Semana Santa, 
vestir, las costumbres sexuales, la manera de divertirse y expresarse, incluso el propio devenir cotidiano está impuesto por un Estado que salvaguarda celosamente la moral católica. Por otro lado, las masas estaban permanentemente movilizadas en acontecimientos religiosos multitudinarios: en procesiones, en infinidad de ejercicios espirituales, en continuas vigilias para la adoración nocturna o en afirmaciones políticas que la mayoría de las veces culminaban con una solemne misa de campaña ${ }^{38}$. Se puede afirmar, sin lugar a dudas, que el pueblo español en su totalidad fue convertido en una grey permanente movilizada. Durante los años de la posguerra los seminarios se llenarán de jóvenes adoctrinados que formarán una verdadera legión dispuesta a difundir y defender la religión católica por España y por el mundo. Los niños, educados en casi su totalidad por las órdenes religiosas, eran continuamente alentados en el sacrificio, encareciéndoles que aportasen su óbolo dominical a las misiones, para que el ejército de Dios pudiese seguir su labor

las procesiones eucarísticas y para el viático de los enfermos; los rosarios a la Virgen, las fiestas de la patrona; los actos religiosos de las cofradías y hermandades". También en S. G. Payne, El catolicismo español, Barcelona, Planeta, 1984, pág. 231. Según Rafael Calvo Serer, en "La Iglesia en la vida pública española desde 1936”, Arbor, n 91 y 92, julio-agosto de 1953, pág. 290: "La presencia de la Iglesia es una realidad en la vida española, en todas partes: en el hogar y en la escuela, en la oficina y en la calle, en la fabrica y en el cuartel, en la Universidad y en los espectáculos, en las diversiones, en las costumbres y hasta en las relaciones íntimas". Vid. Rafael Abella, La vida cotidiana bajo el régimen de Franco, Madrid, Temas de Hoy, 1996, pág. 106. Igualmente en Antonio Ghiorelli, Tiranni, da Hitler a Pol Pot, gli uomini che anno insaguinato el novecento, Milán, Mondadori, 2001, pág. 155.

${ }^{38}$ Ejemplo de esto son las Asambleas Eucarísticas que se llevan a cabo en muchos lugares de nuestra geografía. Así, en la Asamblea Eucarística de Azpeitia durante la procesión se congregaron 25.000 personas, y en el Congreso Eucarístico de Vizcaya se concentraron 70.000 personas. Vid. Javier Sánchez Erauskin, Por Dios hacia el Imperio, Donostia, 1995, pág. 34 y ss. La denuncia de la utilización propagandística de las misas de campaña por el régimen se encuentra presente en importantes miembros de la Iglesia que no comulgaban con él, como fueron el arzobispo Vidal y Barraque y su vicario general Rial. Vid., Hilari Raguer, La pólvora y el incienso. La Iglesia y la Guerra Civil española (1936-1939), Barcelona, Península, 2001, pág. 382 y 401. 
catequizadora del mundo. Incluso la propia vida administrativa del Estado estaba determinada por la Iglesia de tal forma que los registros eclesiásticos tenían más validez que los propios registros estatales. En definitiva, durante esta primera época las relaciones entre el Estado franquistas y la Iglesia Católica eran tan buenas que no se hacia fácil su distinción ${ }^{39}$.

\section{España una gran POTENCIA CATÓlica totalitaria}

En un artículo publicado en 1942, Francisco Javier Conde sostenía, siguiendo las tesis de Daskalakis y Carl Schmitt, que el Estado totalitario es algo inseparable de la "guerra total" $"$. La moderna guerra total solamente se podía afrontar mediante una movilización íntegra de todos los recursos con los que contaban los Estados. La posibilidad de movilización absoluta de los Estados en la época contemporánea se producía por la confluencia de tres factores que el propio Conde sintetizaba en "la democratización, la idea nacional y el principio revolucionario"

La movilización total cancela la distinción entre combatientes y no combatientes. El carácter total de la movilización hace que ámbitos de la realidad que no eran militares, como la economía, la propaganda, e incluso las energías psíquicas y morales de los que no

${ }^{39}$ Luis García San Miguel, "Estructura y cambio del régimen político español", Sistema, n 1, enero de 1973, pág. 83. Joan Vidal, "Iglesia y sociedad en la España franquista", Cuadernos Ruedo Ibérico, no 36, abril-mayo de 1972, pág. 11, "Desde el punto de vista institucional, la Iglesia se inserta de modo eminente en el aparato político del $<<$ Nuevo Estado $>>$, usufructuando determinadas parcelas del poder".

${ }^{40}$ Francisco Javier Conde, "El Estado totalitario como forma de organización de las grandes potencias", Escorial, Cuaderno 23, Madrid, 1942, pág. 373: "El concepto del Estado totalitario nació vinculado, no por azar sino por esencia, al concepto de guerra total". El mismo texto vuelve aparecer en su obra Introducción al Derecho Político Actual, Madrid, ed. Escorial, 1942.

${ }^{41}$ F. J. Conde, Teoría y sistemas de las formas políticas, Madrid, Instituto de Estudios Políticos, 1944, pág. 202. 
combaten, se vean también involucrados en la confrontación hostil; perseguían con este tipo de movilización poner todos y cada uno de los medios con los que cuenta la nación en su conjunto al servicio de una sola idea: "vencer al enemigo"

Pero este enemigo es también un enemigo total, porque todas sus fuerzas materiales y espirituales se dirigen con la máxima tensión posible contra el rival como único objetivo. Esta posibilidad de la guerra total y de un adversario total son las que hacen que surja el Estado totalitario como mejor forma de organización política frente al enemigo total. Por lo tanto, la posibilidad de enfrentarse a la guerra total hace imprescindible que el Estado moderno se configure como una gran potencia ${ }^{43}$ económica y militar.

Para Conde es evidente que el Estado totalitario, más apto para alcanzar una movilización total como respuesta a la guerra total, constituye la forma perfecta de organización política de una gran potencia en su plenitud. Como quiera que sea, el Estado totalitario es la única posibilidad de organización de las grandes potencias para hacer frente a la posibilidad real del desencadenamiento de la guerra total.

Así las cosas, Conde, se encuentra con el gran problema de encuadrar a la España franquista en esta forma de organización específica. Sale del paso diciendo que los supuestos reales que han dado nacimiento al nuevo Estado español incitan a inscribirlo en el ámbito de los llamados Estado totalitarios. La idea límite que justifica la organización estatal totalitaria en España es la forja de una "catolicidad universal". En este intento de realizar la idea límite, por utópica que pueda ser, "cuenta con un pueblo a quien ninguna

${ }^{42}$ Carl Schmitt, "Sobre la relación entre los conceptos de guerra y enemigo", recogido dicho trabajo en el libro El concepto de lo político, Alianza, Madrid, 1991, pág. 138.

${ }^{43}$ Conde, Teoría y sistemas de las formas politicas, ob. cit. pág. 383, sostiene que la pugna de las grandes potencias modernas es, "en posibilidad, lucha total, porque el enemigo se ha convertido cualitativamente en posible enemigo total". 
empresa, por alta que fuese, ha asustado jamás" ${ }^{44}$. Conde defiende que España, aunque no es una gran potencia moderna a la europea, puede ser una gran potencia a la española, apoyada en factores distintos de movilización. Los españoles deben ser movilizados desde su raíz por lo religioso, porque España, como especificaba Corts, es "una gran potencia en lo espiritual" ${ }^{45}$, dispuesta a la movilización total de todos sus recursos para luchar en una verdadera guerra total contra los enemigos de la fe. Más tarde, Conde apostilla que el Estado español es la única forma política contemporánea que ha transpuesto de veras el horizonte moderno de la neutralidad inscribiéndose resueltamente en el horizonte cristiano. Toda gran potencia, en principio, debe contar con una realidad imperial, es decir, las potencias tienen que poseer un ámbito "espacial de gran extensión" ${ }^{46}$. El Imperio es algo consustancial a las grandes potencias materiales, pero España, que es una potencia espiritual, debe tener una realidad imperial en consonancia.

Será este afán de emprender la ruta imperial que consiga adscribir a todos los pueblos hispánicos en un compromiso de unidad que hace posible la consecución de fines gigantescos. Así, los 26 puntos de la Falange Española proclamaban abiertamente que "Tenemos voluntad de Imperio. Afirmamos que la plenitud histórica de España es el Imperio" ${ }^{47}$. Ahora bien, el Imperio español, en opinión de Antonio Tovar, se diferencia del imperialismo porque éste no se cuida de crear una cultura, a semejanza de la que España ha creado en América; en cambio, el Imperialismo se dedica a aprovecharse

${ }^{44}$ F. J. Conde, Introducción al Derecho político actual, Madrid, Ediciones Escorial, 1942, pág. 356 y 357.

${ }^{45}$ José Corts Grau, "Motivos de la España eterna", Revista de Estudios Políticos, nº 9, Madrid, 1943, pág. 23.

${ }^{46}$ F. J. Conde, Introducción al Derecho político actual, ob. cit., pág. 357.

${ }^{47}$ Punto $n^{\circ} 3$, "Norma programática de la Falange Española", recogida en José Antonio Primo de Rivera, Obras Completas, Dirección General de Propaganda, Madrid, 1951, pág. 496. 
de los pueblos débiles ${ }^{48}$. Luego las expansiones territoriales y conquistas, compañeras casi siempre de los Imperios o derivaciones lógicas de ellos, no son, ni pueden ser, elementos fundamentales de la constitución de un Imperio ${ }^{49}$. Entretanto, Sánchez Reyes dirá que existen Imperios "de grandes extensiones los unos, de pequeños territorios los otros [...] Imperios asiáticos y despóticos, e Imperios que, ciegos instrumentos de la Providencia, llevan al mundo el germen de una idea civilizadora, Imperios cristianos a los que falta nervio y savia, y su vida es leve; y un Imperio, sólo un Imperio en la Historia, un Imperio católico, universal por su influencia civilizadora, que incorpora razas, que transfundió la sangre, que dio a los pueblos, el más bello ejemplo de hermandad, que se realizó la obra evangelizadora más grandiosa que se ha visto en los siglos" ${ }_{50}$.

Señalaba Onieva que la misión de catolización universal le había sido impuesta a España por su propio destino, "porque sin duda

${ }^{48}$ Antonio Tovar, El Imperio de España, Valladolid, 1931, donde se dice que "nuestro imperialismo no va a ser un imperialismo económico", citado en S. G. Payne, El régimen de Franco, Madrid, Alianza, 1987, pág. 282. Un estudio amplio sobre el imperialismo, Gay Vicente, Qué es el Imperialismo, Madrid, 1941, define lo que se debe entender por imperialismo y pasa revista a los diferentes imperialismos existentes.

${ }^{49}$ Sánchez Reyes, «Nuestro concepto de Imperio", Revista Universidad de Oviedo, $\mathrm{n}^{\circ}$ 2, 1940, pág. 12. Mariano Puigdollers, "La paz, como dimensión espiritual de nuestro Imperio", en Revista de la Universidad de Madrid, 1941. pág. 106, consideraba la paz como uno de los elementos esenciales con dimensión espiritual del concepto de Imperio Español.

${ }^{50}$ Sánchez Reyes, ob. cit., pág. 15. Parecida forma de interpretar el imperialismo la encontramos en Eleuterio Elorduy, La idea de Imperio en el pensamiento español y de otros pueblos, Madrid, Espasa-Calpe, 1944, pág. 163, donde reseña: “por patriotismo y por el criterio católico en que se inspira nuestro pensamiento, propondremos dar instintivamente la primacía del concepto español de Imperio.

¿Puede haber un Imperio más noble que el de una soberanía humana llamada a realizar en la tierra un plan divino? ¿Puede haber un cetro más sagrado que el que ha sido recibido de las mismas manos de Dios?’. También en Juan Contreras y López de Ayala (Marqués de Lozoya), "El Imperio español del siglo XVI y XVII como ambición ecuménica", Boletín de la Asociación Católica Nacional de Propagandistas, n ${ }^{\circ} 264$, 1-3-1941, pág. 2 y 3. 
España era merecedora de ella" ${ }^{51}$. Por eso, la idea del Imperio español es la idea del Imperio católico. "Su ideal extremo será el establecimiento de la unidad católica en el mundo entero" ${ }_{52}$.

Entiende la doctrina franquista que cuando se habla de la nueva vocación de Imperio o de ruta imperial de España se trata de retomar el camino imperial abandonado, poniendo la espada otra vez al servicio de la fe y la civilización. Se trata de abrir de nuevo los brazos para sacrificarse por todos, frente a los nuevos peligros mundiales. Sólo sobre esa base "el Movimiento Nacional de 1936, aun antes de acabar de reconquistar a España, tiene alma y sentido imperial" ${ }_{53}$. Pero las circunstancias de España distan mucho de ser como las del siglo XVI para imponer el catolicismo por la fuerza de la espada. Esto es lo que lleva a Santaló Rodríguez de Viguri a decir que el Imperio nuevo español tiene que irremediablemente "ser concreción de lo cultural en un grado máximo, ya que la Cultura es, como dice Fermín Izurdiaga del Imperio de España, misión del Espíritu" ${ }^{54}$. La preeminencia imperial española ya no se muestra mediante el poderío de sus ejércitos sino en la misión de sus relaciones culturales que intentan "religar los distintos pueblos en la unidad cultural de salvación" ${ }_{55}$. La nueva voluntad de Imperio

${ }^{51}$ Antonio J. Onieva, „España, Despierta! (Lo que es el Nacional Sindicalismo), Valladolid, 1940, pág. 70 y 75.

${ }^{52}$ Manuel García Morente, Ideas para una filosofia de la Historia de España, Universidad de Madrid, 1943. pág. 80. También en Salvador de Lissarrague, "Esencia de lo Español”, en Curso de Formación Política, S. E. U., Madrid, 1945, pág. 74.

${ }^{53}$ Sánchez Reyes, ob. cit., pag. 21.

${ }^{54}$ José Luis Santaló Rodríguez de Viguri, Introducción a la política del nuevo Imperio, Valladolid, 1938, pág. 196.

${ }^{55}$ Alfonso García Valdecasas, "Relaciones culturales y política exterior", Revista de Estudios Políticos, no 3 1941, pág. 259. Pablo Antonio Cuadra, "Política internacional y política universal de España”, Revista de Estudios Políticos, Madrid, nº 9, 1943, pág. 165, dice: la labor conquistadora del imperio español "es darnos como madre y misionera la lección de espiritualidad que ha de enlazarnos dentro de la libertad un poderío capaz de imponer al mundo su nueva ruta católica”. Según Lorenzo Delgado Gómez 
de España estará "inseparablemente unida a la idea de misión y de influencia civilizadora y cultural" ${ }_{56}$.

La potencia espiritual que entendían era España necesitaba, para su plena realización, un Imperio espiritual, ecuménico y evangelizador. El Imperio español pretende proyectar un nuevo humanismo, "como concreción del mundo cristiano" ${ }_{57}$, en el ámbito de la hispanidad ${ }^{58}$. Ese nuevo humanismo, "es de perfil y tono imperial, puesto que Imperio significa autoridad, tradición, fuerza, exaltación y cultura legendaria" ${ }_{59}$. Esta nueva hispanidad es la que obliga a España a organizarse como "un Estado fuerte, con imperio, un Estado totalitario" ${ }^{\circ}$.

\section{EL NACIONALSINDICALISMO COMO TOTALITARISMO HUMANISTA}

Las posiciones totalitarias, por lo general, intentan producir interpretaciones en las que no se expresa explícitamente la reducción del individuo a simple instrumento o medio del Estado que inevitablemente concluye en la negación del hombre. Al contrario, sus formulaciones teóricas se presentan muy frecuentemente intentando "revalorizar al individuo a través de esa vinculación total al Estado; dirán ser incluso más auténticamente personalistas en cuanto que su resultado será, según se dice, una idea más elevada

Escalonilla, Imperio de papel: Acción cultural y política exterior durante el franquismo, Consejo Superior de Investigaciones Científicas, Madrid, 1992, pág. 47, este imperialismo español es "esencialmente pacífico e intelectual".

${ }^{56}$ Julián Pemartín, Teoría de Falange, Madrid, Sección Femenina de F.E.T. de la JONS, 1941, pág. 19.

${ }^{57}$ Salvador de Lissarrague, "Sentido de la Hispanidad", Revista de Estudios Políticos, nº 9, 1943, pág. 173 .

${ }^{58}$ Cfr. Alfonso Ascanio, España Imperio. El nuevo humanismo y la Hispanidad, Ávila, 1939, pág. 58.

${ }^{59}$ Salvador de Lissarrague, ob. cit. pág. 164.

${ }^{60}$ A. J. Onieva, ob. cit., pág. 72. 
del hombre, una imagen idealizada, ética y espiritual, realizada precisamente en la identificación con el Estado" ${ }_{61}$. La doctrina franquista también tomará este derrotero al pretender, con su visión del totalitarismo humanista, encontrar en el Estado totalitario la forma más perfecta de salvaguardia y realización de los valores personales y espirituales del hombre.

El humanismo del totalitarismo español vendrá defendido por teóricos de diferente sesgo ideológico dentro del espectro político que sostuvo al régimen. Por una parte, se encontraban los católicos, representados por Ruiz Giménez, quien señalaba que el totalitarismo español no es "un totalitarismo más", es específicamente español, y no es copiado del italiano o del alemán, sino que es cristiano y humano ${ }^{62}$. También, desde posiciones católicas, Eloy Montero esgrimía que las nuevas corrientes totalitarias eran las únicas capaces de salvar a la humanidad del peligro comunista, pero debían ser encauzadas por los valores humanistas propios de la filosofía pareja al cristianismo ${ }^{63}$. El católico Corts Grau definirá que la personalidad humana necesariamente se tiene que desarrollar sumisa al Estado en un carácter de colaboración, porque cuanto más acusada y cultivada se encuentre la personalidad, más "rico caudal de energía fresca se puede ofrecer al Estado" ${ }_{64}$.

El monárquico José Pemartín expresaba que la doctrina de Hegel, respecto al absolutismo formal del Estado, es la que

${ }^{61}$ Elías Díaz, "Sustanciación de lo colectivo y Estados totalitarios", en Anuario de Filosofia del Derecho, tomo VIII, 1961, pág. 77.

${ }^{62}$ Joaquín Ruiz Giménez, La concepción institucional del Derecho, Madrid, Instituto de Estudios Políticos, 1944, pág. 16. El propio autor nos dice: "Como no nos asustan las palabras, nos decidimos a emplear el título de totalitario, pero queriendo dar a entender con él la sumisión de todos los individuos y de todas las fuerzas políticas al bien común de la Patria, que a su vez se ordena al bien común de la humanidad".

${ }^{63}$ Cfr. Eloy Montero, Los Estados modernos y la Nueva España, Montepío Diocesano Vitoria, 1936, pág. 228.

${ }^{64}$ José Corts Grau, "El Estado y la personalidad humana”, Ecclesia, no 9, 1 de mayo de 1941, pág. 19. 
determina la substancialidad jurídica de los "Fascios modernos" 65 en su concreción totalitaria. Este absolutismo jurídico hegeliano en España toma su carácter absoluto en el humanismo católico ${ }^{66}$.

El que de una forma definitiva estructurará los parámetros fundamentales de la elaboración teorética del Totalitarismo Humanista fue Luis Legaz Lacambra ${ }^{67}$, quien ya en 1937 veía como necesidad inminente en el Nuevo Estado el llevar a cabo una tarea educativa de proyección del totalitarismo humanista ${ }^{68}$. Legaz construyó su teoría del totalitarismo humanista desde la crítica a la tesis del abate Sturzo sobre la incompatibilidad entre el cristianismo y el Estado totalitario. Legaz se manifiesta contrario a la idea de Sturzo de que el Estado totalitario es la forma "más clara y explícita del Estado panteísta". En contraposición, sostiene que esto no se puede esgrimir del Estado totalitario que fue el de la Contrarreforma española, el cual se totalizó no para servir a la raza, a la nación o a la clase, sino para prestar servicio a la propia Iglesia y a toda la cristiandad en su conjunto, lanzando todo su potencial militar contra la herejía, monopolizando la enseñanza católicamente y negando la libertad personal y política en el sentido que establecía el propio Syllabus.

Legaz se opone radicalmente a la identificación entre Estado totalitario y el Estado panteísta hegeliano. Reconoce que ni la idea nacionalsocialista ni la fascista cuentan con una clara impregnación hegeliana, pero sí admite que donde verdaderamente se unen la filosofía hegeliana y las ideologías estatales de tipo totalitario será

${ }^{65}$ José Pemartín, ob. cit., pág. 49, identifica absolutismo formal hegeliano del Estado con el Estado totalitario.

${ }^{66}$ José Pemartín, ob. cit., pag. 51.

${ }^{67}$ Tengamos en cuenta que Luis Legaz Lacambra antes de comenzar la guerra civil formaba parte de los Amigos de Esprit en España y llegó a ser corresponsal de la revista dirigida por Mounier. Luego era notoria su vocación humanista-personalista. Vid. Benjamín Rivaya, “Quién fue el padre de Federico Sánchez?, (Legaz versus Semprum)", Sistema, no 144, Madrid, 1998, pág. 80

${ }^{68}$ Cfr. Luis Legaz Lacambra, "El humanismo totalitario como tarea de una educación hispánica”, Revista de Educación Hispánica, n 3, 1937, págs. 15 a 21. 
en la "reelaboración metafísica de los problemas del Estado y del hombre" 69 , porque estas nuevas ideologías pretenden darle al Estado dignidad y valor ético frente al propio sistema liberal-burgués. Afirma que la filosofía de Hegel pertenece por completo al círculo de la filosofía cristiana y occidental, en cuanto filosofía del espíritu, como filosofía de la libertad y la personalidad, y sin embargo su doctrina del Estado suele ser motivo de escándalo. Por todo ello, para Legaz, el Estado hegeliano representa la sublimación de la libertad y la personalidad, pues el Estado sería una de las manifestaciones del espíritu objetivo, el cual es voluntad libre y no un poder objetivo ajeno o contrario a la subjetividad, sino el mismo espíritu del individuo, en tanto que lo capacita para comprenderse como sujeto y ser libre frente a toda determinación exterior. Se inclina por proclamar que la auténtica libertad sólo se puede alcanzar dentro del Estado. Así entiende que el Estado hegeliano está al servicio de la verdad objetiva y de los principios de la vida moral (en cuanto principios éticos), por lo que se garantiza la libertad por la verdad. En su opinión, Hegel fundamenta filosóficamente los regímenes totalitarios modernos, que buscan también denodadamente la proyección de la libertad en la existencia de los pueblos. Incluso llegará a confrontar el Estado derivado de la filosofía hegeliana con la idea estatal que desprende el tomismo.

El Estado totalitario, según Legaz, es la misma sociedad organizada que tiende a la realización ética de una cierta idea política o religiosa. Será la sociedad con sus "unidades naturales" familia, sindicato y municipio, quienes politizan lo social ascendiéndolas a la categoría de estatales sin que dejen de ser sociales, haciendo que el Estado abarque todo lo que es propia sociedad: Estado económico, cultural, religioso, etc. Este Estado que engloba toda la sociedad aspira, sobremanera, a poner todo al servicio de una idea

69 Luis Legaz Lacambra, Introducción a la teoría del Estado Nacionalsindicalista, Barcelona, Bosch, 1940, pág. 203 y pág. 207. 
"política", totalitaria y nacional, la idea de la Patria como síntesis de lo trascendente.

Sostiene Legaz que en el Estado nacionalsindicalista el valor propio y específico es la idea de Patria, pero "No es la Patria en abstracto, cualquier Patria, la que honra, sino precisamente España, que es una unidad de destino que la diferencia en lo universal de cualquiera otro. El Estado es la forma de existencia ético-política de un pueblo, pero lo que le confiere el máximo valor ético es que en él se realizan los valores concretos que constituyen la esencia de la Patria". Por lo tanto, el "Estado nacionalsindicalista es la realización en la existencia ético-política del pueblo español, de los valores morales altísimos que encarna la idea de España. Idea que sólo en el Estado tiene realización. Cuando España niega su propia idea, cuando desconoce su auténtica esencia, su Estado decae y muere. Por eso, en esta circunstancia trágica y gozosa en que España se recobra a sí misma, es un imperativo ético la tarea de instaurar de nuevo un Estado, ético y jurídico, totalitario y nacionalsindicalista, católico y humano, que salve la libertad profunda y objetive la voluntad esencial de los españoles y que muestre su íntima verdad y necesidad espiritual realizándose como Imperio”.

En su opinión la nueva cristiandad, que pretende la realización de la unidad del hombre mediante un ideal humanista cristiano, solamente puede ser forjada en un humanismo integral, totalitario. Ésta, según el criterio de Legaz, será la aportación más original de España, frente a otros pueblos que solamente consiguen rehacer el acento totalitario sobre el Estado, y estas circunstancias son las que hacen al Estado nacionalsindicalista ser totalitario, al estar asentado "sobre un humanismo totalitario" 70.

Legaz se opondrá rotundamente a quienes intentan esgrimir el personalismo, en cuanto humanismo integral, como un valor político frente al fascismo, al aprovechar la contraposición persona-Estado,

${ }^{70}$ Luis Legaz Lacambra, ob. cit., pág. 224 y 228. 
en la que el individuo, el hombre, la persona quedarían aniquilados y absorbidos por el moderno Leviathan, porque, si Maritain había sido el encargado de dar una base filosófico-teológica, convirtiendo el personalismo en un humanismo integral, según Legaz, será José Antonio el que consiguió establecer en su discurso ideológico un verdadero humanismo integral, al afirmar que el respeto a la libertad profunda de la persona se alcanza solamente cuando se estima al propio hombre portador de valores eternos. Tenemos, pues, que no sólo ha sido perfilado un concepto nuevo y entero de la vida, sino que queda perfectamente delimitado este esencial personalismo de todo individualismo, liberalismo o personalismo político. Es entonces cuando se ve que "el personalismo aplicado a la política es un fraude, porque no tiene en cuenta al hombre total, en su unidad, sino sólo la $<<$ persona $>>$ superpuesta a la Ciudad [Estado], como en Maritain" "71, porque el Estado, a juicio de Legaz, con ser altísima cosa, nunca puede ser la más alta; así "el Estado es ético, pero no es la eticidad; el Estado puede ser totalitario, pero a condición de que realice totalitariamente la libertad esencial del hombre, la vida moral de la persona"72. El único humanismo posible es el integral o totalitario, más integral que el de Maritain que sólo es un mero personalismo, porque la realización de la libertad humana es solamente posible cuando el hombre funde su destino en la consecución de los destinos patrios ${ }^{73}$. De forma que el hombre no será verdaderamente libre en el Estado "cuando posee libertad de discrepar, sino cuando le presta aquel asentimiento

${ }^{71}$ Luis Legaz Lacambra, ob. cit., pág. 248.

${ }^{72}$ Luis Legaz Lacambra, "Prólogo a la obra de Giovanni Gentile", Los fundamentos de la Filosofia del Derecho, Buenos Aires, Losada, 1944, pág. 12.

${ }^{73}$ Luis Legaz Lacambra, Introducción a la teoría del Estado Nacionalsindicalista, ob. cit., pág. 249, 250 y 251. Sostiene que "el humanismo totalitario que postula el nacionalsindicalismo puede ser la base de un Estado totalitario en el que los valores humanos y personales estén garantizados como valores eternos e intangibles." 
profundo que implica una fusión espiritual" ${ }^{74}$, y será en esta plena configuración cuando el hombre consigue realmente ser libre. En opinión de Legaz es a España y a su nacionalsindicalismo a quienes corresponde elaborar la nueva concepción humanista, en la que el respeto al hombre en cuanto hombre resulte una verdad fecunda que el mundo debe aprender ${ }^{75}$. Destaca que el humanismo totalitario español es una de las características más acusadas del pensamiento de José Antonio, porque "sólo se supera de verás al hombre cuando se le estima, como nosotros lo estimamos, portador de valores eternos" ${ }^{\prime 76}$.

\section{Vi. El totalitarismo subjetivo de los CATólicos}

Si entre la doctrina franquista existía un casi unánime acuerdo en calificar al Estado español como totalitario, no existía la misma armonía a la hora de ver el grado de intervencionismo que el Estado y el partido debían tener en el nuevo Estado español que se pretendía totalitario. Así, los falangistas se proclamaban partidarios de una intervención absoluta del Estado y del partido en todos los ámbitos de la sociedad. A este totalitarismo estatalista a ultranza de los falangistas se opondrían, en cierta manera, los católicos, quienes, partiendo de las premisas vaticanas, desarrollaron la teoría del totalitarismo subjetivo.

${ }^{74}$ Luis Legaz Lacambra, "Prólogo a la obra de Karl Larenz", La filosofía contemporánea del Derecho y del Estado, Madrid, ed. Revista de Derecho Privado, 1942, pág. 4.

${ }^{75}$ Vid, Luis Legaz Lacambra, "Sentido humanista del Nacionalsindicalismo", Jerarquía, no 3, 1938, pág. 251.

${ }^{76}$ Luis Legaz Lacambra, Introducción a la teoría del Estado Nacionalsindicalista, ob. cit., pág. 253. Este humanismo totalitario "se considera, pues, occidental, español y cristiano, y eso le lleva a comenzar la revolución, la construcción de un orden nuevo, por el individuo, que encarne en valor libre y eterno [...]. No es para el individuo del individualismo para lo que pide respeto y libertad, sino para el hombre, íntegramente, esto es cristianamente entendido". 
El máximo exponente de esta modalidad de totalitarismo fue el padre Joaquín Azpiazu, quien, en 1939, apuntaba que el naciente "Estado Católico Español" debía huir de constituirse en un totalitarismo estatal absoluto o extremo, porque tal sistema es contrario a la realización del bien común, que, según la doctrina pontificia, es el fin ultimo del Estado católico ${ }^{77}$. El Estado católico, al que el autor denomina "Estado Personalista"78, debe distinguirse del Estado liberal, pero también del Estado absolutista exagerado, que Azpiazu identifica con el totalitarismo estatal abusivamente entendido a la manera que mostraba la famosa cita mussoliniana: "Todo por el Estado, nada contra el Estado y nada fuera del Estado". En opinión de Azpiazu, esto representaba la posición del Estado con respecto a los individuos, no la elisión de éstos con relación a un querer desconocido para ellos. Son estas circunstancias las que lo llevan a sostener que el Estado católico (personalista) es una vía intermedia que se puede sintetizar en el mínimo necesario de libertad que "es el poder que todo hombre tiene de ejercer y desarrollar su actividad física, intelectual y moral conforme a su destino personal, sin que ni el prójimo ni el Estado puedan poner otras restricciones que las que sean necesarias al destino de todos"79. Joaquín Azpiazu no se declara en ningún momento antitotalitario. Ahora bien, arremeterá duramente contra un tipo

${ }^{77}$ Cfr. Joaquín Azpiazu, El Estado Católico (Lineas de un ideal), Madrid - Burgos, ed. Rayfe, 1939, pág. 16 y 17.

${ }^{78}$ J. Azpiazu, ob. cit., pág. 145: "El Estado Católico, pues, no debería ser ni liberal ni autoritario en exceso, ni adorador galante de la libertad con desprecio de la autoridad, ni exaltador de una autoridad que sometiese y sojuzgase a su arbitrio a la libertad. Este es el Estado en que más estrechamente se abrazan la libertad y la autoridad, hijas de Dios ambas, nacidas para una misma finalidad, la de enaltecer y realizar la persona humana; aquélla, sublimándola y haciéndola capaz de merecer sobrenaturalmente la vida eterna; ésta, dirigiéndola y ayudándola al desenvolvimiento y desarrollo de la personalidad". Aquí vemos cómo el Estado católico personalista tiene idénticas connotaciones al establecido por el "Totalitarismo Humanista".

${ }^{79}$ Ibídem 146. 
de totalitarismo muy preciso, y no frente al totalitarismo en sentido general, estableciendo una marcada distinción entre dos tipos de totalitarismo. Así argumenta: "Para muchos -equivocadamente, a nuestro juicio- Estado totalitario significa Estado que asume en sus manos la dirección y control de todos los asuntos de la nación. Este concepto es totalmente falso y hay que desterrarlo. De ser esto verdad, Estado totalitario equivaldría a Estado socialista, o por lo menos, pariente muy próximo de él. Porque esa es precisamente la característica del Estado socialista: la centralización de todas las actividades del país" ".

Para este Estado totalitario viene a ser lo mismo que Estado autoritario ${ }^{81}$, siendo diferente del Estado dictatorial, tipo de Estado que impregna de forma sustancial las manifestaciones políticas mussoliniana y hitleriana. El Estado corporativo, que él defiende como mejor forma de organización de la sociedad, ha de ser totalitario. Con esto no quiere indicar que el Estado haya de absorber todas las funciones de las economías privadas y públicas y deba tener en su mano todas las fuerzas de la nación, lo que sería completamente anticristiano. De ahí que, para Azpiazu, el Estado Español sería un Estado totalitario, pero radicalmente distinto del régimen socialista y comunista centralizante, ya que "este régimen totalitario no es ni el que quiere España, ni menos el tradicional español"\$2. El totalitarismo defendido por Azpiazu se consigue solamente con "un Estado fuerte con un Poder enérgico y respetado, no mediatizado; venerado como divino, no como meramente humano; que una todas las fuerzas sociales hacia un fin - el bien común -, [...]; pero todo ello con el máximo respeto de la santa

${ }^{80}$ J. Azpiazu, "Estado Tradicional y Estado Totalitario", Razón y Fe, octubre, 1937, pág. 187 y 188; también en El Estado Católico, ob. cit., pág. 160.

${ }^{81}$ Cfr. J. Azpiazu, El Estado Corporativo, Ed. Razón y Fe, Madrid, 1936, pág. 351. La primera edición es de 1934.

${ }^{82}$ J. Azpiazu, "Estado Tradicional y Estado Totalitario", ob. cit., pág. 188; y en El Estado Católico, ob. cit., pag. 161. 
libertad individual, dentro de su esfera" ${ }^{\text {"3 }}$.

Azpiazu mantiene que el Estado totalitario español se debe desarrollar dentro del genuino espíritu católico, no pudiendo vaciarse de los moldes de cuño legítimo tradicional en los que irremediablemente tiene que moverse. Tendrá que ser, en su opinión, un totalitarismo de talante nacional donde las influencias extranjeras nunca desvirtúen sus raíces tradicionales. Criticará a los partidarios del totalitarismo a ultranza, que se encuentra diametralmente opuesto al espíritu católico y que empiezan por suponer que el bien común, cuyo garante principal es el Estado, solamente se realiza a través de éste. Esto llevará al padre Azpiazu a decir que existen en la sociedad instituciones o algunas sociedades naturales, como son la familia, el municipio o la profesión organizada ${ }^{84}$, que ejercen su misión natural de promoción hacia el bien común. No sólo estas sociedades naturales promueven la consecución del bien común, también las instituciones culturales tienden hacia esta misma realización social. Por tal razón, Azpiazu muestra su repulsa expresa ante los que creen que el bien común lo alcanzaría mejor aquel Estado que todo lo absorbe, porque para él la manera preferible de conseguir "el Estado el bien común es realizarlo, en cuanto es posible, por medio de las instituciones naturales inferiores existentes y no por sí mismo; es decir, dejando de ser totalitario a ultranza"85. Pues si el Estado quiere llevar a cabo el bien común destruyendo este principio de subsidiariedad, rompiendo de forma clamorosa con la familia, la profesión, la Iglesia, o la vida cultural, aunque siempre sea con la mejor de las intenciones, resultaría antinatural y entraría en pugna con el bien individual, haciendo de los hombres verdaderos esclavos, porque la función del Estado es la de procurar

\footnotetext{
${ }^{83}$ J. Azpiazu,"Estado Tradicional...", pág. 190; y en El Estado Católico, ob. cit., pág. 163.

${ }^{84}$ Cfr. J. Azpiazu, "Entre el individuo y el Estado", Razón y Fe, septiembre diciembre de 1939, pág. 57 y 58.

${ }^{85}$ J. Azpiazu, El Estado Católico, ob. cit., pág. 170.
} 
el mayor bien común a la sociedad, llevándolo a cabo forzosamente a través de los mismos individuos que componen la sociedad, procurando a la vez compatibilizar el máximo de bien común con el bien individual, pues el Estado es para el individuo y no al revés.

El Estado totalitario a ultranza, en opinión de Azpiazu, hay que rehuirlo a toda $\operatorname{costa}^{86}$, y esto se puede evitar no tomando crudos totalitarismos como copia ${ }^{87}$. Así describirá al Estado totalitario español de la siguiente manera: "no ha de ser totalitario en sentido objetivo o a ultranza, sino en sentido subjetivo, debe estar dotado de un Poder total y soberano, fuerte y no mediatizado, encauzador y no entrometido; que trabaje por acostumbrar al individuo y a la sociedad a cumplir sus deberes primordiales" ". Este tipo de totalitarismo es el que Azpiazu califica como subjetivo, que es aquel que "para todo aquello que es de competencia del Estado según sus propios fines, se atenga a las direcciones del Estado y del régimen y defensa de él la totalidad de los ciudadanos de un Estado; que cabe, por tanto, atribuir al Estado y al régimen un totalitarismo que podremos llamar subjetivo. Pero no podemos decir lo mismo de un totalitarismo objetivo en el sentido de que la totalidad de los ciudadanos deba atenerse al Estado y depender de él, y peor aún de sólo él, o de él principalmente, para todo aquello que pueda ser necesario para el desenvolvimiento de su vida individualmente,

${ }^{86}$ Ibídem pág. 172. Juan José Ruiz Rico, en El papel político de la Iglesia Católica en la España de Franco, Madrid, Tecnos, 1977, pág. 123, sostenía: "La Iglesia rechazaba el totalitarismo siempre que amenazaba su posición de privilegio o contradecía sus doctrinas". De forma más genérica en Guy Hermet, «Les fonctions politiques des organisations religieuses dans les régimes à pluralisme limité», en Revue Française de Science Politique, Vol XVIII, no 3, 1973, pag. 443.

${ }^{87}$ Cfr. J. Azpiazu, El Estado Católico, ob. cit., pág. 176. Podemos apreciar cómo Azpiazu intenta desligar al régimen español de otros regímenes que se conceptualizan como totalitarios, como era el caso de nacionalsocialismo alemán, consecuencia de la encíclica contra el nazismo del Papa Pío XI en el año 1937.

${ }^{88}$ J. Azpiazu, "El Estado Tradicional y Estado Totalitario", ob. cit., pág. 192. 
espiritual y sobrenatural""s9. El totalitarismo objetivo o a ultranza será por lo tanto anticristiano, porque este totalitarismo objetivo, hace "pasar todos los poderes por medio de un Poder supremo, que es el político. Todas las organizaciones profesionales, instituciones escolares, pasan o están dominadas por el sector político, que las controla y sigue" ${ }^{90}$.

Azpiazu aboga por que frente a este tipo de totalitarismo objetivo que no permite a la Iglesia desempeñar su papel mediante sus instituciones escolares, culturales, etc, debe surgir en el horizonte político español el poder tradicional que, identificándose plenamente con el totalitarismo subjetivo, deja autónomos todos los poderes institucionales, pero manteniéndolos el jefe en su mano, ligándolos a su persona o jefatura, y es en este totalitarismo tradicional en el que el Estado actuará “dejando la máxima libertad a las funciones que él tiene obligación de cumplir, únicamente por vía subsidiaria, cuando la sociedad falta a sus deberes" ${ }^{{ }_{91}}$. Esto no menoscabaría el poder tradicional o totalitarismo subjetivo, pues el poder puede ser tan fuerte como en el régimen totalitario objetivo, ya que puede mantener en una mano todas las riendas, no mediatizadas por su organismo político, sino unidas directamente en la misma cabeza del Estado, que mantiene así todos los poderes.

Finalmente, Azpiazu hace patente la coincidencia del totalitarismo subjetivo con el régimen diciendo: "en diversas ocasiones se ha dicho por parte del jefe del Estado español y de algunos de los que junto a él gobiernan la nueva España, que el Estado que ha de surgir del

${ }^{89} \mathrm{~J}$. Azpiazu, El Estado Católico, ob. cit., pág. 177. Parece ser que la teoría del totalitarismo subjetivo fue expresada por primera vez por el Papa Pío XI en una carta dirigida al arzobispo de Milán, el cardenal Schustes. Vid. sobre el tema P. Milza y S. Berstein, Le fascisme italien, Paris, Ed. Seuil, 1980, pág. 270. Igualmente a Leonard Schapiro, El Totalitarismo, Fondo Cultura Económica, México, 1972, pag. 62 y Alberto Acquarone, L' organizzazione dello Stato totalitario, Torino, 1965.

${ }^{90} \mathrm{~J}$. Azpiazu, El Estado Católico, ob. cit., pág. 178.

${ }^{91}$ J. Azpiazu, Orientaciones cristianas del Fuero del Trabajo, Burgos, ed. Rayfe, 1939, pág. 21. 
desenlace de esta sangrienta guerra, ha de tener dos caracteres $[\ldots]$ : ha de ser un Estado tradicional que se sirva la savia de la riquísima tradición medieval española, y a la vez un Estado totalitario, fuerte y riguroso" $"$. Por todo ello, el Estado totalitario español "significa, ante todo y sobre todo -y ello está en el ánimo del pueblo-, Estado fuerte y vigoroso, representativo de las fuerzas del país" ${ }^{93}$.

En esta misma línea, José Soler y Díaz Guijarro establecía que los estados totalitarios están perfectamente de acuerdo con la doctrina de la Iglesia, en cuanto robustecen la autoridad y producen una integración de fuerzas. Defenderá como modelo a seguir por la nueva España el totalitarismo subjetivo, según el cual: "todo aquello que es de competencia del Estado, según sus propios fines, se atenga a las direcciones del Estado y del régimen y dependan de él la totalidad de los ciudadanos" ${ }^{94}$.

El canónigo de la catedral de Palencia, Laureano Pérez Mier, se manifestaba también partidario de calificar el totalitarismo del nuevo Estado español, que afirma el valor intangible de la dignidad humana, de la integridad y de la libertad del hombre, como subjetivo, estimando que nada tiene que ver con el totalitarismo absoluto repudiado por Pío $\mathrm{XI}^{95}$.

\section{El Estado hispánICO TOTALITARIO SOLIDRISTA}

El profesor de Derecho Político de Zaragoza Luis Del Valle en la segunda edición de su obra Hacia una nueva fase histórica del Estado declaraba que el movimiento español "nacional solidarista" ${ }_{96}$ aspiraba

${ }^{92}$ J. Azpiazu, "El Estado Tradicional y Estado Totalitario", ob. cit., pág. 118.

${ }^{93}$ J. Azpiazu, El Estado Católico, ob. cit., pág. 187.

${ }^{94}$ José Soler y Díaz Guijarro, "Concepto del Estado", Boletín de la Asociación Católica Nacional de Propagandistas, no 247, 15-4-1940, pág. 3.

${ }^{95}$ Cfr. Laureano Pérez Mier, Iglesia y Estado Nuevo, Madrid, Fax, 1940, pág. 465.

${ }^{96}$ Luis Del Valle, Hacia una nueva fase histórica del Estado, Zaragoza, Atheneum, 1937, pág. 15. 
a crear un Estado hispánico, de honda raigambre nacionalista, que trabaje en pos de un verdadero desarrollo nacional. Entendía que el Estado nacionalista era la mejor forma suprema política que la comunidad nación podía adoptar en busca de la consecución de su ideal nacional. Es entonces cuando el Estado se transforma en una persona moral, en una organización teleológica ${ }^{97}$. Esto no quiere decir que el Estado tenga un fin en sí mismo y para sí, sino que es una organización que sirve como medio a un fin más alto: realizar el destino nacional. Así, la fuerza y el poder propio del Estado se dignifican al poner toda su voluntad al servicio de un ideal ${ }^{98}$. De este modo, la concepción nacionalista se integra y complementa con el concepto solidarista, "preparando el terreno fecundo del estado totalitario" ${ }^{99}$.

El solidarismo que pretende Del Valle es orgánico, porque prescinde del puro individuo, que queda convertido en un órgano de la comunidad y, por lo tanto, del Estado. La superación del individualismo y el establecimiento del nexo de unión perfecto entre el individuo y la comunidad lo consigue a través de la doctrina de la personalidad, que considera al hombre en tanto miembro de una sociedad organizada, en la que solamente pueda vivir en cuanto ejerza un oficio con la mayor perfección posible en interés de la comunidad misma ${ }^{100}$. De esta manera consigue transformar el Estado gregario de la mayoría en un Estado nuevo, cuyo carácter principal sería la solidaridad nacional que persigue esta nueva personalidad. Del Valle catalogará a esta nueva doctrina personalista como nacionalista-solidaria-orgánica, de la cual considera que son sus expresiones históricas el nacionalsocialismo alemán, el fascismo italiano y el nacional-sindicalismo español.

${ }^{97}$ Cfr. Luis del Valle, Derecho Politico General, Zaragoza, 1943, pág. 44.

98 Cfr. Luis del Valle, El Estado Nacionalista, Totalitario, Autoritario, Zaragoza, Atheneum, 1940, pág. 119.

${ }^{99}$ Ibídem, pág. 124

${ }^{100}$ Cfr. Luis del Valle, Democracia y jerarquía, Zaragoza, Atheneum, 1938, pág. 39. 
Cree el profesor de derecho político de la Universidad de Zaragoza que en toda "Comunidad perfecta" el individuo tiene que dejar de ser egoísta, ya sea conscientemente o por coacción normativa e imperante del Estado, para convertirse, mediante este tipo de investidura orgánica, en servidor de una misión social, de una función pública que sirve al ideal de destino. La consecución de este objetivo necesita que se produzca una gran revolución espiritual, cultural y mística, que se construya una nueva filosofía social, "que nos vuelva profundamente a Dios, que aspira a que los hombres lleguemos a ser sus órganos en el mundo, para el cumplimiento del Deber y el triunfo de la Justicia”.

Del Valle estima que la única dirección salvadora se encuentra en el deber como único camino para llegar al ideal divino de salvación. "Por el Deber hacia Dios. He ahí la verdad suprema y definitiva". El deber ofrece dos modalidades fundamentales: el deber del individuo, como puro individuo, que persigue la virtud y la perfección personal, cuya dirección suprema toca a la Iglesia; y el deber del individuo, en cuanto ser social, en cuanto órgano de la comunidad misma para su propio destino, "que es camino de renunciación de su yo, de superación personal, de subordinación y coordinación, cuya suprema dirección toca al Estado" ${ }^{101}$. Entonces tanto la Iglesia como el propio Estado se convierten en instrumentos de Dios en la historia para conseguir el triunfo del deber, como único camino directo que lleva a Dios y, por lo tanto, hacia la única y verdadera felicidad.

Esta nueva filosofía social cristiana, siempre siguiendo la opinión de Del Valle, diluye la concepción dialéctica liberal, de la existencia de una sociedad frente al Estado, y en su lugar establece una sociedad que se transforma en una comunidad nacional con vida sustantiva propia que, a su vez, se constituye en el Estado mismo. El Estado que así se forma se organiza totalitariamente para lograr

${ }^{101}$ Luis del Valle, El Estado Nacionalista, Totalitario, Autoritario, ob. cit., pág. 130. 
una intercomunicación constante con la sociedad. Es mediante el totalitarismo como el Estado alcanza su plenitud al conseguir que exista una verdadera concepción política y la nación-comunidad logra su máxima perfección, porque todo lo nacional se hace político y todo lo político se organiza y realiza en función nacional. Esta nueva forma de Estado totalitario tiene que impregnarlo todo, por lo que debe ordenar y tomar a su cargo cada uno de los contenidos de la existencia social. Al penetrarlo todo el Estado, los problemas económicos y sociales se transforman en problemas políticos, la sociedad es plenamente asimilada por el Estado, modificando sus diferentes áreas en: "Estado económico, Estado cultural, Estado previsor, Estado benéfico" ${ }_{102}$.

A tenor de lo anterior, Del Valle entiende que el Estado totalitario es aquel cuyo poder ante ningún ámbito de la vida humana se detiene. El poder lo alcanza todo, lo condiciona todo y lo regula todo, por lo que el Estado totalitario tendrá una estrecha relación con el Estado autoritario.

Frente al Estado liberal, que representa el mínimo de intervención, surge esta concepción orgánica totalitaria de máxima intervención y actividad, para obtener la realización más perfecta de la solidaridad nacional en la consecución del destino nacional. Es la confluencia de la voluntad individual y nacional en la idea de destino la que consigue transformar la voluntad puramente personal en orgánica ultrapersonal.

\section{A MOdO DE CONCLUSIÓN}

El régimen franquista, pese a lo que algunos pretenden, surge con una clara e ineludible vocación totalitaria, que se constata en los grandes discursos institucionales, declaraciones programáticas, entrevistas periodísticas e incluso en la propia legislación. La

${ }^{102}$ Ibídem, pág. 149. 
España franquista buscaba la construcción de un Estado totalitario en España, siguiendo los modelos totalitarios de Italia y Alemania. Si en estos países la idea límite finalista era la defensa de nación y la raza, respectivamente, en España era la defensa y expansión de la religión católica en el mundo, considerado consustancial a la propia esencia nacional española. De forma que el Estado totalitario español intentó poner todas sus posibilidades materiales al servicio del catolicismo.

Por otro lado, la Iglesia en ningún momento renegó de un Estado que llegó a imponer con violencia sus postulados morales a toda la sociedad española; es más, estaba tan de acuerdo con este tipo de Estado que incluso admitió un cierto grado de ingerencia en su sistema organizativo.

Este singular tipo de totalitarismo no sólo fue pretendido por los falangistas, sino que fue admitido de buena gana por el resto de las facciones políticas que apoyaron el régimen: monárquicos, católicos e incluso tradicionalistas. Las cuatro interpretaciones del totalitarismo español que aquí estudiamos son una muestra de cómo toda la doctrina intentó caracterizar el régimen como totalitario.

En este sentido, podemos decir que los valores católicos que impregnaban el sustrato ideológico conservador (que la sociología norteamericana y el propio Linz utilizan para no caracterizar al Estado franquista como totalitario) eran precisamente lo que esgrimía la doctrina política española franquista de finales de los treinta y principios de los cuarenta para fundamentar la necesidad de la constitución de un Estado totalitario al servicio y expansión de la religión católica. 
IX. FuENTES

\section{Bibliografía}

Abella, Rafael, La vida cotidiana bajo el régimen de Franco, Madrid, Temas de Hoy, 1996.

Acquarone, Alberto, L' organizzazione dello Stato totalitario, Torino, Giulio Einaudi, 1965

Álvarez Bolado, Alfonso, El experimento del Nacionalcatolicismo (19391975), Madrid, Cuadernos para el Dialogo, 1976.

Ascanio, Alfonso, España Imperio. El nuevo humanismo y la Hispanidad, Ávila, 1939.

AzPiAzu, Joaquín, El Estado Católico (Lineas de un ideal), MadridBurgos, Rayfe, 1939.

Orientaciones cristianas del Fuero del Trabajo, Burgos, Rayfe, 1939

Botтi, Alfonso, Cielo y dinero. El Nacionalcatolicismo en España (18811975), Madrid, Alianza, 1992.

Cantero, Pedro, La hora Católica en España, Madrid, Ruta, 1942.

Conde, Francisco Javier, Introducción al Derecho Político Actual, Madrid, Escorial, 1942.

Teoría $r$ sistemas de las formas políticas, Madrid, Instituto de Estudios Políticos, 1944.

Delgado Gómez Escalonilla, Lorenzo, Imperio de papel: Acción cultural y política exterior durante el franquismo, Madrid, Consejo Superior de Investigaciones Científicas, 1992

DíAz, Elías, Notas para una Historia del pensamiento español actual, Madrid, Edicusa, 1974.

EL Pensamiento español eN la eRA de Franco, Madrid, Tecnos, 1983. 
Elorduy, Eleuterio, La idea de Imperio en el pensamiento español y de otros pueblos, Madrid, Espasa - Calpe, 1944.

Fenech, Miguel, La posición del juez en el Nuevo Estado, Madrid, EspasaCalpe, 1941

Franco Bahamonde, Francisco, Palabras del Caudillo, Madrid, F.E., 1939.

Friedrich, Carl J y Brzezinski, Z. K., Totalitarian Dictatorship and Autocracy New York, Harper, 1956.

García Morente, Manuel, Ideas para una filosofía de la Historia de España, Universidad de Madrid, 1943.

Gentile, Emilio, "El fascismo y la vía italiana al totalitarismo", en Pérez Ledesma, Manuel (comp), Los riesgos para la democracia. Fascismo y neofascismo, Madrid, Pablo Iglesias, 1997.

Ghiorelli, Antonio, Tiranni, da Hitler a Pol Pot, gli uomini che anno insaguinato el novecento, Milán, Mondadori, 2001.

Giménez Caballero, Ernesto, La nueva catolicidad. Teoría general sobre el Fascismo en Europa: en España, Madrid, La Gaceta Literaria, 1933.

Gomáriz, Enrique, "La reproducción del pasado", en Muñón DE LARA, Manuel y otros, Ideología y sociedad en la España contemporánea. Por un análisis del franquismo, Madrid, Cuadernos para el Dialogo, 1977.

Gómez Pérez, Rafael, Política y religión en el régimen de Franco, Barcelona, Dopesa, 1976.

Hills, George, Monarquía, República y Franquismo, 1868-1974, Madrid, San Martín, 1975.

Inkeles, Alex, "Totalitarism and Ideologie", en la obra de Carl J. Friedrich (ed.), Totalitarism, Cambridge, Harvard University Press, 1954. 
Jiménez Campo, Javier, "Crisis política y transición al pluralismo en España (1975-1978)", en Predieri, Alberto y García de Enterría, Enrique La Constitución española de 1978, Madrid, Civitas, 1980.

Laín Entralgo, Pedro, Los valores morales del Nacionalsindicalismo, Madrid, 1941.

Legaz Lacambra, Luis, Introducción a la teoría del Estado Nacionalsindicalista, Barcelona, Bosch, 1940.

Prólogo a la obra de Karl Larenz, La filosofía contemporánea del Derecho y del Estado, Madrid, Revista de Derecho Privado, 1942.

Prólogo a la obra de Giovanni Gentile, Los fundamentos de la Filosofía del Derecho, Buenos Aires, Losada, 1944.

Panorama Político Español Contemporáneo, Madrid, Colegio Mayor Universitario "Marqués de la Ensenada", 1968.

Linz, Juan J., "An Authoritarian Regimen: The Case of Spain”, en Eric Allard e Yrjo Littunen (comps), Clevages, Ideologies, and Party Systems, Westermarck Society, 1964. Dicho trabajo fue publicado en castellano en "Una teoría del régimen autoritario. El caso de España”, en FraGA, Manuel y otros, La España de los años setenta III: El Estado y la política, Madrid, Moneda y Crédito, 1974.

De Lissarrague, Salvador "Esencia de lo Español", Curso de Formación Politica, S. E. U., Madrid, 1945.

M. Rama, Carlos, La crisis española del siglo XX, Madrid, F. C. E., 1976.

Manollesco, Mihail, El Partido Único, Zaragoza, 1938.

Maritain, Jacques, Les droits de l'homme et la loi naturelle, New York, La Maison française, 1942. 
Menéndez Reigada, Ignacio G. Catecismo patriótico español, Salamanca, 1937.

Milza, P. y Berstein, S., Le fascisme italien, Paris, Seuil, 1980.

Montero, Eloy, Los Estados modernos y la Nueva España, Montepío Diocesano Vitoria, 1936.

Moreno Herrero, Francisco (Marqués de la Eliseda), Fascismo, Catolicismo, Monarquía, Madrid, Fax, 1935.

El sentido fascista del Movimiento Nacional, Santander, Aldus, 1939.

Onieva, AntonioJ., ¡España, Despierta! (Lo que es el Nacional Sindicalismo), Valladolid, 1940.

Payne, Stanley G. El catolicismo español, Barcelona, Planeta, 1984.

EL RÉGIMEN de FRANCo, Madrid, Alianza Universidad, 1987.

Pemartín, José, Qué es <<lo nuevo>>, Madrid, Espasa-Calpe, 1940.

Pemartín, Julián Teoría de Falange, Madrid, Sección Femenina de F.E.T. de la JONS, 1941.

Pérez Mier, Laureano, Iglesia y Estado Nuevo, Madrid, Fax, 1940.

Portero, José Antonio "La Revista de Estudios Políticos (19411945), en Ramírez, Manuel y otros, Las fuentes ideológicas de un régimen (España 1939-1945), Barcelona, Lábor, 1978.

Primo de Rivera, José Antonio, Obras Completas, Madrid, Dirección General de Propaganda, 1951.

Ramírez, Manuel, "La ideología en el régimen totalitario. El caso de España”, en RAmírez, Manuel y otros, Las fuentes ideológicas de un régimen (España 1939-1945), Zaragoza, Pórtico, 1978.

Raguer, Hilari, La pólvora y el incienso. La Iglesia y la Guerra Civil española (1936-1939), Barcelona, Península, 2001. 
Richards, M. "Constructing the Nationalist State. Self Sufficiency and Regeneration in the Early Franco Years", en MARMolinero, Claire y Smith, Angel (edts), Nationalism and the Nation in the Iberian Peninsula, Washington/Oxford, Berg, 1996.

Ruiz Giménez, Joaquín, La concepción institucional del Derecho, Madrid, Instituto de Estudios Políticos, 1944.

Ruiz Rico, Juan José, en El papel político de la Iglesia Católica en la España de Franco, Madrid, Tecnos, 1977.

Sáez Alba, A. (Pseudónimo Rojas Marcos, Alejandro) de La otra $<<\cos$ a nostra >>, la Asociación Católica Nacional de Propagandistas, París, Ruedo Ibérico, 1974.

Sánchez Erauskin, Javier, Por Dios hacia el Imperio, Donostia, 1995.

SÁnchez Recio, Glicerio, "La coalición reaccionaria y la confrontación política dentro del régimen franquista", en Tusell, Javier, Pecharroman, Julio y Montero, Feliciano, Estudios sobre la derecha española contemporánea, Madrid, U.N.E.D., 1993.

Santaló Rodríguez de Viguri, José Luis, Introducción a la política del nuеvo Imperio, Valladolid, 1938.

Schapiro, Leonard, El Totalitarismo, México, Fondo Cultura Económica, 1972.

Schmitт, Carl, "Sobre la relación entre los conceptos de guerra y enemigo", El concepto de lo político, Alianza, Madrid, 1991.

Sevillano Calero, Francisco, "Totalitarismo, fascismo y franquismo: el pasado y el fin de las certidumbres después del comunismo", en Moreno Fonseret, Roque y Sevillano Calero, Francisco (eds), El franquismo. Visiones y balances, Universidad de Alicante, 1999, 
Silió, César, Trayectoria y significación de España: Del tiempo viejo al tiempo nиеvo, Madrid, Espasa-Calpe, 1939.

Soler y Díaz Gujjarro, José "Concepto del Estado", Boletín de la Asociación Católica Nacional de Propagandistas, n 247, 15-4-1940.

Sueiro, Daniel y Díaz Nosty, Bernardo Historia del franquismo, Madrid, Sarpe, 1986.

Tovar, Antonio, El Imperio de España, Valladolid, 1931.

Valor histórico y filosófico del sindicalismo, en el I Congreso Sindical de la Falange, Madrid, 1940.

de Urrutia, Federico, Por qué la Falange es Católica, Madrid, 1942

Del Valle, Luis, Hacia una nueva fase histórica del Estado, Zaragoza, Atheneum, 1937.

Democracia y jerarquía, Zaragoza, Atheneum, 1938.

El Estado Nacionalista, Totalitario, Autoritario, Zaragoza, Atheneum, 1940.

VIÑAs, Ángel, La otra cara del Cuadillo. Mitos y realidades en la biografia de Franco, Barcelona, Crítica, 2019.

2. Hemerografía

Abellán, Manuel y Oskam, Jeroen, "Función social de la censura eclesiástica. La crítica de libros en la revista Ecclesia", fournal of Interdisciplinary Literary Studies, No 1, 1989.

AzPiazu, Joaquí, "Estado Tradicional y Estado Totalitario", Razón y $\mathrm{Fe}$, octubre, 1937.

Entre el individuo y el Estado, Razón y Fe, septiembre - diciembre de 1939. 
Botтi, Alfonso, "El franquismo en la historiografía italiana y la mirada del otro sobre los relatos de otras miradas", Ayer; $\mathrm{n}^{\circ}$ 31, 1998.

Calvo Serer, Rafael,"La Iglesia en la vida pública española desde 1936", Arbor, no 91 y 92, julio-agosto de 1953.

Conde, Francisco Javier, "El Estado totalitario como forma de organización de las grandes potencias", Escorial, Cuaderno 23, Madrid, 1942.

Contreras y López de Ayala, Juan (Marqués de Lozoya), "El Imperio español del siglo XVI y XVII como ambición ecuménica", Boletín de la Asociación Católica Nacional de Propagandistas, $\mathrm{n}^{\circ}$ 264, 1-3-1941

Corts Grau, José, "El Estado y la personalidad humana”, Ecclesia, $\mathrm{n}^{\circ}$ 9, 1 de mayo de 1941.

Motivos de la España eterna, Revista de Estudios Políticos, $\mathrm{n}^{\circ}$ 9, Madrid, 1943.

Guadra, Pablo Antonio, "Política internacional y política universal de España", Revista de Estudios Políticos, Madrid, nº 9, 1943

Chueca, Ricardo y Montero, José Ramón, "Fascista y católico: el pastiche ideológico del primer franquismo", Revista de Occidente, $n^{\circ} 223$, diciembre de 1999.

DíAz, Elías, "Sustanciación de lo colectivo y Estados totalitarios", en Anuario de Filosofia del Derecho, tomo VIII, 1961.

García SAn Miguel, Luis, "Estructura y cambio del régimen político español”, Sistema, nº 1, enero de 1973.

García Valdecasas, Alfonso, "Relaciones culturales y política exterior", Revista de Estudios Políticos, no 3 1941, pag. 259.

Garrigues, Joaquín, "Il nuovo ordine in Spagna, sindicati verticali e corporazioni”, en Archivio di Studi Corporativi, Roma, 1939. 
Giménez Caballero, Ernesto, "Ripercussioni del fascismo in Ispagna”, Gerarchia, Roma, 1932.

González Prieto, Luis Aurelio, "La concreción teórica del Partido Único franquista" en la Revista de Estudios Políticos, N ${ }^{\circ} 141$, 2008.

El Debate sobre la Constitución en el Primer franguismo, Revista de Estudios Políticos, $\mathrm{n}^{\circ} 155$.

Hermet, Guy, «Les fonctions politiques des organisations religieuses dans les régimes à pluralisme limité», en Revue Française de Science Politique, Vol XVIII, nº 3, 1973

Jiménez Campo, Javier "Rasgos básicos de la ideología dominante 1939 - 1945", en la Revista de Estudios Políticos, n 15, nueva época, 1980.

Laín Entralgo, Pedro, "Idea falangista del hombre", en la Revista del Colegio Mayor "Fiménez Cisneros, Universidad de Madrid, $\mathrm{n}^{\circ}$ 2, 1943.

Legaz Lacambra, Luis, "El humanismo totalitario como tarea de una educación hispánica", Revista de Educación Hispánica, n 3 , 1937.

De Lissarrague, Salvador, "Estado y partido en la coyuntura española", Arriba, 15 de septiembre de 1940.

Sentido de la Hispanidad, Revista de Estudios Políticos, nº 9, 1943.

de Maeztu, Ramiro, La Nación, 4 de abril de 1927.

Maravall, José Antonio, "El totalitarismo, régimen europeo", Arriba, 26 de septiembre de 1940.

De Miguel Rodríguez, Amando "La < < Sociología del Franquismo $>>$ revisada", Papers, no 6, 1976. 
Puigdollers, Mariano, "La paz, como dimensión espiritual de nuestro Imperio", en Revista de la Universidad de Madrid, 1941.

Oltra, Benjamín y de Miguel, Amando, "Bonapartismo y catolicismo: una hipótesis sobre los orígenes ideológicos del Franquismo", revista Papers, $n^{\circ} 8$.

Pérez Ledesma, Manuel, en "Una Dictadura $<<$ Por la Gracia de Dios >>", Historia Social, n ${ }^{\circ}$ 20, 1994.

Rivaya, Benjamín, “¿Quién fue el padre de Federico Sánchez?, (Legaz versus Semprum)", Sistema, nº 144, Madrid, 1998.

SÁnchez Reyes, «Nuestro concepto de Imperio”, Revista Universidad de Oviedo, $\mathrm{n}^{\circ}$ 2, 1940.

DE LA Souchère, Élène, «Un Catolicisme Totalitaire», Les Temps Moderns, $\mathrm{n}^{\circ}$ 100, París, 1954.

VIDAL, Joan, "Iglesia y sociedad en la España franquista", Cuadernos Ruedo Ibérico, no 36, abril-mayo de 1972.

3. Webgrafía

Navarro, Vincenç, "Las derechas españolas y el fascismo", en http://www.correntroig.org/spip.php?article916\&lang=ca. 


\section{Estudios JuRÍdICOS}


